\title{
Pengaruh Kompensasi dan Job Insecurity Terhadap Turnover Intention Pada Buruh di Kabupaten Kudus (Studi Kasus Pada PT. Pura Barutama Unit Offset Divisi Produksi)
}

\author{
Farizka Ayuningtyas ${ }^{1, *}$ \& Hari Susanta Nugraha ${ }^{2}$ \\ ${ }^{1,2}$ Departemen Administrasi Bisnis, Fakultas Ilmu Sosial dan Ilmu Politik, Universitas Diponegoro \\ *Email: Farizka20@gmail.com
}

\begin{abstract}
Human resources is an important factor in the company as it can support the achievement of goals in the company. Hence, the company must maintain human resources in order not to leave the company and find work in other companies. So to suppress human resources especially laborers out of the company (turn over intention) the company should pay attention to the factors that support turnover intention, including compensation and job insecurity factors. This study aims to determine the effect of compensation and job insecurity on turnover intention in case study at PT. Pura Barutama Unit Offset Production Division. This type of research using explanatory research and sampling technique using non-probability sampling technique with purposive sampling method, data collection technique using questionnaire method. The number of samples used in this study as many as 100 respondents. This research uses quantitative and qualitative analysis with validity test, reliability test, correlation coefficient, coefficient of determination, simple regression and multiple test, and significance of $T$ and $F$ test. The results of this study indicate that the compensation and job insecurity variables have a strong influence on turnover intention variables. The compensation variable has a strong influence as well as the direction of negative relationship to the turnover intention variable. While job insecurity variables have a very strong influence and have a positive relationship direction to the variable turnover intention.
\end{abstract}

\begin{abstract}
Abstraksi Sumberdaya manusia merupakan faktor penting dalam perusahaan karena dapat menunjang keberhasilan tercapainya tujuan pada perusahaan. Sehingga perusahaan harus memelihara sumberdaya manusia agar tidak meninggalkan perusahaan dan mencari pekerjaan di perusahaan lain. Maka untuk menekan sumber daya manusia khususnya buruh keluar dari perusahaan (turnover intention) maka perusahaan harus memperhatikan faktor-faktor penunjang turnover intention, antara lain faktor kompensasi dan job insecurity. Penelitian ini bertujuan untuk mengetahui pengaruh yang diberikan oleh kompensasi dan job insecurity terhadap turnover intention pada studi kasus di PT. Pura Barutama Unit Offset Divisi Produksi. Tipe penelitian ini menggunakan explanatory research dan teknik pengambilan sampel menggunakan teknik non-probability sampling dengan metode purposive sampling, teknik pengumpulan data menggunakan metode kuesioner. Jumlah sampel yang digunakan dalam penelitian ini sebanyak 100 responden. Penelitian ini menggunakan analisis kuantitatif dan kualitatif dengan uji validitas, uji reliabilitas, koefisien korelasi, koefisien determinasi, uji regresi sedehana dan berganda, serta signifikansi uji T dan Uji F. Hasil dari penelitian ini menunjukkan bahwa variabel kompensasi dan job insecurity memiliki pengaruh yang kuat terhadap variabel turnover intention. Variabel kompensasi memiliki pengaruh yang kuat serta arah hubungan yang negatif terhadap variabel turnover intention. Sedangkan variabel job insecurity memiliki pengaruh yang sangat kuat serta memiliki arah hubungan yang positif terhadap variabel turnover intention.
\end{abstract}

Keywords: Job Insecurity; Turnover Intention; Compensation

\section{Pendahuluan}

Dalam suatu perusahaan sumber daya manusia merupakan salah satu faktor yang memegang peranan penting dalam menjalankan roda perusahaan. Sumber daya manusia merupakan aset penting dalam suatu perusahaan.Sumber daya manusia dalam suatu perusahaan seringkali disebut dengan istilah pekerja karyawan. Para pekerja dalam suatu perusahaan memiliki tugas dan kewajiban masing-masing tetapi tetap mengarah pada tujuan perusahaan. Kemampuan suatu pekerja memiliki dampak yang besar bagi keberhasilan perusahaan dalam mencapai tujuan. Semakin baik kemampuan pekerja dalam menjalankan tugasnya maka akan lebih mudah juga perusahaan mencapai tujuan yang diinginkan. Oleh karena itu, perusahaan harus 
memeilihara dan memperhatikan para pekerjanya agar para pekerja merasa nyaman saat melakukan pekerjaannya. Dalam masyarakat status sebagai pekerja sangat jamak ditemui sebagai mata pencaharian seseorang, pekerja yang bertugas di bagian manufaktur atau produksi barang umum disebut dengan sebutan buruh. Sedangkan pekerja yang bertugas di sektor manajemen atau jasa sering disebut dengan istilah karyawan. Buruh atau pekerja yang mengandalkan kekuatan fisik memiliki jumlah lebih banyak dari pekerja yang mengawasinya. Hal ini disebabkan dari sekian puluh atau ratus buruh hanya perlu beberapa orang yang bertugas memanajeri atau mengsupervisi.

Banyaknya masyarakat yang berprofesi sebagai buruh di Kabupaten Kudus, membuat tingkat persaingan antar sesama buruh meningkat. Hal ini sering menimbulkan perasaan tidak nyaman yang dirasakan oleh para buruh terkait dengan pekerjaannya atau lingkungan kerja mereka. Jika hal tersebut terus terjadi, buruh akan memiliki niat untuk meninggalkan perusahaan tersebut dan mencari perusahaan lain yang dirasa cocok dan nyaman untuknya. Keinginan untuk keluar dari perusahaan dan mencari pekerjaan di perusahaan lain disebut dengan turnover intention. Turnover intention pada suatu perusahaan dapat memberikan dampak negatif pada perusahaan, seperti apabila buruh yang keluar dari perusahaan memiliki kinerja yang bagus maka perusahaan kehilangan buruh tersebut dan berdampak pada tingkat produktivitas perusahaan yang menurun, perusahaan juga mengeluarkan biaya awal, seperti biaya perekrutan, biaya pelatihan, periklanan, pemberhentian dan lain sebagainya. Selain itu jika perusahaan belum menemukan pengganti buruh tersebut, maka buruh lainnya akan menanggung beban yang lebih besar dari biasanya untuk mengerjakan pekerjaan buruh yang masih belum dapat penggantinya.

Turnover intention dapat disebabkan oleh beberapa faktor, salah satunya adalah factor kompensasi yang diterima buruh/pekerja tidak sesuai dengan apa yang diharapkan. Kompensasi merupakan salah satu kebutuhan utama yang dibutuhkan oleh para pekerja selaku manusia untuk memenuhi kebutuhan hidupnya. Selain faktor kompensasi, ada faktor lain yang tidak kalah penting yang menyebabkan turnover intention yaitu faktor job insecurity yang dirasakan oleh buruh yang bekerja di suatu perusahaan. Menurut Suciati dkk., (Septiari \& Ardana, 2016) job insecurity adalah ketidakberdayaan untuk mempertahankan kesinambungan yang diinginkan dalam kondisi kerja yang terancam.

Objek pada penelitian ini yaitu di PT. Pura Barutama Unit Offset Divisi Produksi, hal ini dikarenakan jumlah buruh pada PT. Pura Barutama Unit Offset Divisi Produksi selalu meningkat setiap tahunnya. Berdasarkan uraian dan fakta tersebut, maka peneliti memilih judul "Pengaruh Kompensasi dan Job insecurity pada Buruh di Kabupaten Kudus (Studi Kasus pada PT. Pura Barutama Unit Offset Divisi Produksi).

Rumusan masalah dalam penelitian ini adalah: (1) Apakah ada pengaruh antara kompensasi terhadap turnover intention pada Buruh di PT Pura Barutama Unit Offset Divisi Produksi?; (2) Apakah ada pengaruh antara job insecurity terhadap turnover intention padaBuruh di PT Pura Barutama Unit Offset Divisi Produksi?; (3) Apakah ada pengaruh antara kompensasi dan job insecurity terhadap turnover intention pada Buruh di PT Pura Barutama Unit Offset Divisi Produksi?

Tujuan dari penelitian ini adalah: (1) Untuk menganalisis pengaruh antara kompensasi terhadap turnover intention pada Buruh di PT Pura Barutama Unit Offset Divisi Produksi; (2) Untuk menganalisis pengaruh antara job insecurity terhadap turnover intention pada Buruh di PT Pura Barutama Unit Offset Divisi Produksi; (3) Untuk menganalisis pengaruh antara kompensasi dan jobinsecurity terhadap turnover intention pada Buruh di PT Pura Barutama Unit Offset Divisi Produksi. 


\section{Kajian Teori}

Kompensasi

Menurut Hasibuan (2009) kompensasi adalah semua pendapatan yang berbentuk uang atau barang langsung ataupun tidak langsung yang diterima pekerja/buruh sebagai imbalan atas jasa yang diberikan kepada perusahaan. Jenis kompensasi ada 3 macam, yaitu kompensasi langsung, kompensasi tidak langsung dan insentif. Indikator yang digunakan untuk mengukur tingkat kompensasi yang diberikan perusahaan, yaitu: Jumlah upah yang diterima, Jumlah/Jenis Insentif yang diterima, Jumlah/Jenis Tunjangan yang diterima, Cuti yang diterima, dan Asuransi/Jaminan yang diterima.

\section{Job insecurity}

Menurut Smithson dan Lewis (2000) job insecurity adalah kondisi psikologis seseorang (buruh) yang menunjukkan rasa bingung atau merasa tidak aman dikarenakan kondisi lingkungan yang berubah-ubah (perceived impermanance). Kondisi ini muncul karena banyaknya jenis pekerjaan yang sifatnya sesaat atau pekerjaan kontrak. Makin banyaknya jenis pekerjaan dengan durasi waktu yang sementara atau tidak permanen, menyebabkan semakin banyaknya buruh yang mengalami jobinsecurity. Indikator yang digunakan untuk mengukur tingkat job insecurity pada penelitian ini, yaitu: Karakteristik pekerjaan yang diterima, Tingkat persaingan yang terdapat dalam pekerjaan, dan Kepastian yang didapatkan dari tempat bekerja terkait masa depan karir.

\section{Turnover intention}

Menurut Lum et.al dalam Andini (2006) turnover intention adalah keinginan seseorang untuk keluar organisasi, yaitu evaluasi mengenai posisi seseorang saat ini berkenaan dengan ketidakpuasan dapat memicu keinginan seseorang untuk keluar dan mencari pekerjaan lain. Dampak yang ditimbulkan dari tingginya tingkat turnover intention dalam perusahaan yaitu adanya biaya perekrutan, biaya pelatihan, biaya produktivitas dan biaya pemberhentian (Mathis dan Jackson , 2006). Indikator yang digunakan untuk mengukur tinggi atau rendahnya tingkat turnover intention pada suatu perusahaan, antara lain: beban kerja yang diterima, durasi bekerja dalam sehari; hubungan dengan rekan di tempat kerja; hubungan dengan atasan di tempat kerja.

\section{Metode}

Penelitian ini menggunakan tipe penelitian explanatory research atau penelitian penjelasan yaitu penelitian yang digunakan untuk mendapatkan data dari tempat tertentu, tetapi peneliti melakukan perlakuan dalam pengumpulan data. Selain itu penelitian ini juga berusaha mengungkap hubungan antara variabel kompensasi, job insecurity dan variabel turnover intention.

Populasi dalam penelitian ini adalah seluruh buruh yang bekerja pada PT. Pura Barutama Unit Offset Divisi Produksi yaitu sebanyak 375 buruh. Sedangkan sampel yang digunakan dalam penelitian ini yaitu sebanyak 100 responden yang bekerja sebagai buruh di PT Pura Barutama Unit Offset Divisi Produksi. Teknik pengambilan sampel yang digunakan pada penelitian ini adalah dengan teknik probability sampling. Menurut Sugiyono (2010) probability sampling adalah teknik pengambilan sampel yang memberi peluang/kesempatan sama bagi setiap unsur atau anggota populasi untuk dipilih menjadi sampel. Jenis sampling yang digunakan dalam penelitian ini adalah Proportional Random Sampling yaitu teknik pengambilan sampel secara acak pada populasi yang telah ditetapkan sebelumnya (Sugiyono, 2010).

Skala pengukuran dalam penelitian ini yaitu menggunakan skala likert dan menggunakan instrumen berupa kuesioner. Penelitian ini menggunakan teknik kualitatif dan kuantitatif. Analisis kuantitatif menggunakan uji validitas, uji reliabilitas, koefisien korelasi, koefisien determinasi, analisis regresi sederhana dan berganda, uji signifikansi (uji t) dua arah dan uji signifikansi (uji F) dua arah dengan menggunakan program SPSS versi 22.0. 


\section{Hasil}

Hubungan kompensasi terhadap turnover intention memiliki nilai $\mathrm{R}$ sebesar 0,711 yang artinya adalah bahwa variabel kompensasi terhadap variabel turnover intention memiliki hubungan yang kuat apabila dilihat dari kategori yang telah ditentukan sebelumnya. Variabel kompensasi juga memberikan kontribusi sebesar 50,5\% terhadap variabel turnover intention. Hasil dari uji regresi sederhana, nilai koefisien regresi variabel kompensasi memiliki nilai sebesar -0,960, dimana artinya adalah variabel kompensasi mempunyai pengaruh negatif terhadap turnover intention. Sehingga arah hubungan kedua variabel tersebut tidak searah (berlawanan). Sehingga apabila kompensasi yang diberikan PT. Pura Barutama Unit Offset Divisi Produksi tinggi maka turnover intention pada PT. Pura Barutama Unit Offset Divisi Produksi rendah dan begitupun sebaliknya. Kriteria pengujian dalam penelitian ini adalah Ho diterima dan Ha ditolak, apabila -t-tabel $<\mathrm{t}$-hitung $<\mathrm{t}$ tabel, Ho ditolak dan Ha diterima, apabila -ttabel $>$ t-hitung $>$ t-tabel. Dan hasil dari pengujian yang telah dilakukan adalah $\mathrm{t}$ hitung variabel kompensasi adalah $-10>\mathrm{t}$ tabel $(1,984)$, maka Ho ditolak dan $\mathrm{Ha}$ diterima, dimana pengaruh antara variabel kompensasi terhadap turnover intention pada PT. Pura Barutama Unit Offset Divisi Produksi, sehingga semakin rendah kompensasi yang diberikan maka akan ada perubahan terhadap turnover intention pada perusahaan PT. Pura Barutama Unit Offset Divisi Produksi.

Lalu hubungan job insecurity terhadap turnover intention memiliki nilai $\mathrm{R}$ sebesar 0,846 , dimana artinya apabila dicocokkan pada kategori hubungan antara variabel job insecurity terhadap variabel turnover intention sangat kuat. Variabel job insecurity juga memberikan kontribusi terhadap variabel turnover intention sebesar 71,6\%. Hasil dari uji regresi sederhana dari variabel job insecurity terhadap variabel turnover intention memiliki nilai koefisien regresi sebesar 0,569. Koefisien regresi untuk job insecurity sebesar 0,569, menunjukkan bahwa variabel job insecurity mempunyai pengaruh positif terhadap turnover intention. Berdasarkan hal tersebut maka dapat diartikan bahwa jika variabel job insecurity mengalami peningkatan maka akan menyebabkan peningkatan pada turnover intention di PT. Pura Barutama Unit Offset. Seperti kriteria pengujian variabel sebelumnya, hasilnya adalah thitung variabel job insecurity sebesar $(15,709)>\mathrm{t}$ tabel $(1,984)$, maka Ho ditolak dan Ha diterima. Artinya ada pengaruh antara variabel job insecurity terhadap turnover intention pada PT. Pura Barutama Unit Offset Divisi Produksi, sehingga semakin tinggi job insecurity yang diberikan maka semakin tinggi pula tingkat turnover intention pada perusahaan tersebut.

Terakhir adalah membahas variabel kompensasi dan variabel job insecurity terhadap variabel turnover intention. Dari ketiga variabel tersebut menghasilkan nilai $\mathrm{R}$ sebesar 0,906 yang artinya adalah ketiga variabel tersebut memiliki hubungan sangat kuat. Pada koefisien determinasi yang telah diujikan juga didapatkan hasil sebesar $82,1 \%$, dimana artinya adalah bahwa variabel kompensasi dan variabel job insecurity memberikan kontribusi sebesar $82,1 \%$ terhadap variabel turnover intention, sedangkan sebesar 17,9\% dipengaruhi oleh faktor lain. Pada uji regresi linier berganda didapatkan hasil bahwa koefisien regresi untuk variabel kompensasi (X1) adalah 0,51. Berdasarkan angka tersebut maka, variabel kompensasi memiliki pengaruh negatif terhadap variabel turnover intention. Sehingga dapat diartikan bahwa jika terhadap kompensasi yang diberikan rendah maka akan menyebabkan peningkatan pada turnover intention di PT. Pura Barutama Unit Offset Divisi Produksi. Koefisien regresi untuk variabel job insecurity (X2) adalah 0,44 . Berdasarkan angka tersebut maka, variabel job insecurity memiliki pengaruh positif terhadap variabel turnover intention. Berdasarkan hal tersebut, maka dapat diartikan bahwa jika variabel job insecurity semakin tinggi maka akan menyebabkan peningkatan pada turnover intention pada PT. Pura Barutama Unit Offset Divisi Produksi. 


\section{Kesimpulan}

Berdasarkan hasil dari penelitian yang telah dilakukan mengenai pengaruh kompensasi dan jobinsecurity terhadap turnover intention pada PT. Pura Barutama Unit Offset Divisi Produksi dapatditarik beberapa kessimpulan yaitu: (1) Variabel kompensasi dipersepsikan baik oleh responden yaitu $84 \%$ dan sangat baik $16 \%$ sangat baik. Sehingga dapat disimpulkan bahwa kompensasi yang diberikan oleh PT. Pura Barutama Unit Offset Divisi Produksi baik, meskipun masih ada beberapa hal yang perlu diperbaiki; (2) Variabel jobinsecurity dipersepsikan baik oleh responden yaitu $65 \%$, cukup baik yaitu $19 \%$ dan $16 \%$ sangat baik. Sehingga dapat disimpulkan bahwa jobinsecurity di PT. Pura Barutama Unit Offset Divisi Produksi baik, meskipun masih ada beberapa item indikator yang dibawah rata-rata; (3) Variabel turnover intention dipersepsikan sudah baik, meskipun ada sedikit yang memberikan analisis cukup baik. Hal ini dikarenakan ada beberapa item indikator yang masih berada di bawah ratarata.

\section{Saran}

Berdasarkan kesimpulan yang telah dijabarkan di atas, maka diajukan saran saran untuk melengkapi hasil penelitian sebagai berikut: (1) Untuk menekan tingkat turnover intention pada PT. Pura barutama Unit Offset Divisi Produksi sebaiknya lebih diperhatikan lagi kompensasi yang diberikan kepada buruh di PT. Pura Barutama Unit Offset Divisi Produksi. Hal tersebut dapat dilakukan dengan memberikan atau bahkan menambah uang lembur kepada buruh yang bekerja di PT. Pura Barutama Unit Offset Divisi Produksi, dengan memfasilitasi mobil jemputan bagi buruh di PT. Pura Barutama Unit Offset Divisi Produksi atau memberikan bentuk kompensasi yang lain kepada buruh yang bekerja di perusahaan tersebut; (2) Selain itu, untuk menekan tingkat turnover intention pada PT. Pura Barutama Unit Offset Divisi Produksi, sebaiknya dapat dilakukan dengan memperhatikan job insecure pada perusahaan tersebut, seperti dengan memberikan status tetap pada buruh yang telah bekerja dalam kurun waktu yang lama di PT. Pura Barutama Unit Offset Divisi Produksi. Dapat juga memberikan jenjang karir yang jelas bagi setiap buruh yang bekerja di PT. Pura Barutama Unit Offset Divisi Produksi dan lain sebagainya.

\section{Daftar Referensi}

Ajiputra, Mirza Setyawan dan Ahyar Yuniawan. (2016). Analisis Pengaruh $\mathrm{Job}$ insecurity dan Kepuasan Kompensasi terhadap Turnover intention serta Dampaknya pada Kinerja Karyawan (Studi pada PDAM Kabupaten Semarang). Volume 5 No 1.

Andrinirina, Mamihorisoa, Dwipayana IKM dan Sudarsih. (2015). Pengaruh Lingkungan Kerja dan Jobinsecurity terhadap Kinerja dan Turnover intention Karyawan pada Royal Hotel n'loungeJember".

Azis, Fathoni, Halimah Tika Nur dan Minarsih Maria. (2016). Pengaruh Job insecurity, Kepuasan Kerja dan Lingkungan Kerja terhadap Turnover intention Pramuniaga di Gelael Supermarket (Studi Kasus pada Gelael Superindo Kota Semarang)". Volume 2, No 2.

Devi, Ni Luh Mita Sari dan Sudibia Gede Adnyana. (2015). Analisis Pengaruh $J o b$ insecurity dan Kompensasi Finansial terhadap Kepuasan Kerja dan Turnover intention (Studi Kasus pada Karyawan Kontrak di Bali Dynasty Resort). Volume 4, No 4.

Diputra, Y. I. N. Y., \& Mujianti, N. W. (2016). Pengaruh Kompensasi, Kepemimpinan dan Lingkungan Kerja Terhadap Kinerja karyawan Pada Hotel Griya Santrian. E-Jurnal Manajemen Unud, ISSN: 2302-8912, 5(4), 23692395.

Hidayah, Nurul. (2016). Pengaruh Kompensasi terhadap Kinerja Karyawan Melalui Kepuasan Kerja sebagai 
Variabel Intervening (Studi Kasus pada Karyawan Bagian Keuangan dan Akuntansi Universitas Negeri Yogyakarta).

Masdupi, Erni dan Yanita Poni. (2014). Pengaruh Kompensasi, Kepemimpinan Organisasi dan Jobinsecurity terhadap Intention to Turnover pada Dosen Sekolah Tinggi Ilmu Ekonomi Sakti AlamKencana (STIE SAK). Volume 2 No 3.

Putra, Made Surya dan Setiawan I Nyoman Agus. (2016) Pengaruh Job insecurity terhadap Kepuasan Kerja dan Turnover intention pada Karyawan Legian Village Hotel.Volume 5 No 8.

Putrianti, A. D., Hamid, D., \& Mukzam, M. D. (2014). Pengaruh Kompensasi dan Motivasi Kerja terhadap Turnover intention (Studi pada Karyawan PT. TIKI Jalur Nugraha Ekakurir Pusat Malang). Jurnal Administrasi Bisnis (JAB), 12(2), 1-9.

Safi'i Siti Zulaiha. (2015) Pengaruh Budaya Organisasi dan Komitmen Organisasi terhadap Turnover Karyawan pada PT. Massindo Sinar Pratama Tbk. Manado. Volume 3 No 1.

Sandi, F. M. (2014). Analisis Pengaruh Kompensasi dan Job insecurity terhadap Turnover intention (Studi Pada Guru Sdit Asy-Syaamil Bontang).

Septiari, N. K., \& Ardana, I. K. (2016). Pengaruh Job insecurity dan Stres Kerja terhadap Turnoverintention Karyawan pada Hotel Asana Agung Putra Bali. Jurnal Manajemen Unud, 5(10), 64296456. 